\title{
STATE LAWS: SURVIVAL OF THE UNFIT.
}

Should someone suggest to you that in certain fields of law, the States are competing with each other to secure the most inefficient and unsocial form of legislation, you might well be incredulous. Should this same person assert further that the States are hiring experts to examine the laws of all the other States in order to determine which of these are most lax to the individual or corporation regulated and most exploitive of the public, your reply might assume more of the character of a blunter negation. Yet such is the fact in certain branches of our law.

We have two types of laws as we have two types of business. In one field of business, competition brings out all that is desirable; it forces to the front by its iron law of survival of the fittest the best management, the largest savings and the greatest efficiency. It is desirable that the larger portion of business and industry be thus competitive, all copying the merits of others, all eliminating the friction and waste exposed by such competitive comparison. The most efficient survive. So also with most of our legislation. The States send experts and commissions to other States or to Europe to examine their laws, in order to secure what the competitive experience of such governments may have demonstrated to be best. In short the world's experience and learning contributes to the form of most State laws, and the most efficient laws survive.

On the other hand, however, there is a field of law, as in business, in which competition brings out all that is socially undesirable. For example the history of competition between railroads, with their rate wars, rebates and discriminations, has demonstrated that competition in this field of business is wholly undesirable. The same is true, resulting as it does in corrupted business and bankrupted roads, of all public utilities. And today the policy of the State and the Nation is to legalize monopolies wherever competition is indesirable-to substitute one central 
form of control for the guerrilla warfare of the past. Completing our parallel we find that in legislation we have the same conditions, but not the same remedy. In fact so far, no remedy. In our incorporation laws, insurance laws, bird laws and all the laws involving industrial conditions we find the States competing in an unsocial way. Do the States copy the most stringent incorporation or insurance laws? Will any State cut down the hours of labor, introduce machinery safeguards or prevent child labor when its competing neighbor State refuses to enact such reforms? Hardly. It will not put its own citizens at such a disadvantage. The States are industrially competitive and stringent and advanced legislation will put them at a disadvantage with other States. For a State to be conscientious would be synonymous with cutting its own throat. So in all States the unsocial and the unfit laws survive, or at least reform is delayed many years. To state the situation in the mildest form:

"Because of the competition of State units, there is a tendency for the worst form of legislation to become the model of all the others; there is a tendency to drag down advance legislation to the compulsory competitive standard of the worst State laws; conscience is at the mercy of competition and the most elastic conscience rules."

No attempt shall be made to cover the entire field of law for illustrations, nor is it contended that a particular branch of law remains forever in this unwholesome, competitive condition. The examples which follow will demonstrate, however, the fact that there are some fields in which State legislation per se cannot accomplish a desirable result.

The most notorious of our competitive laws are the laws of incorporation. Mr. Amasa Eaton, President of the Commissioners on Uniform State Laws, in his 1902 address ${ }^{1}$ thus summarizes the situation:

"It is useless to attempt to secure the adoption of a uniform incorporation act by the various States, because the trend of legislation in too many of the States, is to enact laws

\footnotetext{
${ }^{1}$ Report, I902-07.
} 
favoring incorporation with a view to the pecuniary returns to the State rather than with a view to adherence to sound principles."

In 1904 the Committee on Uniform Incorporation Law of the same organization reported as follows: ${ }^{2}$

"Each State and Territory, and the District of Columbia, has a corporation law of its own. Each prescribes a different method for the formation of a corporation, gives to the corporation thus formed different powers; imposes different responsibilities upon the corporation itself, and upon its officers and stockholders; prescribes different remedies against it, and provides for a different method of winding up its affairs in case of dissolution.

"Each State and Territory, and the District of Columbia, extends to corporations formed in other States a different degree of welcome or unwelcome when they seek to do business within its borders. They impose different conditions preliminary to the right to transact such business, different responsibilities in connection with the business, and a different rate of tax therefor.

"A company of men desiring to do business of any kind in the State of New York and to incorporate themselves for that purpose, first consult their lawyer on the subject of incorporation and pay him his retaining fee. He examinesif he is not already familiar with the subject-the corporation laws of all the States and Territories in the United States to find out where he can incorporate his clients and give them the greatest advantages from such incorporation. He has to consider

"I. The cost of incorporation and the preliminary license tax in connection therewith;

"2. Annual license taxes thereafter;

"3. The extent of the power which will be vested in the corporation ;

"4. The responsibility of the incorporators;

"5. The ability of the corporation to do business in different States, and

"6. - Last, but not least, what laws will protect the business of his clients best from the curiosity of their rivals and the scrutiny of public officials.

"The different States and Territories, not omitting the District of Columbia, compete for the business. In return for a certain amount to be paid them preliminarily and annually in the way of taxes, they offer the largest possible amount of

\footnotetext{
${ }^{2}$ Report, I904-05.
} 
freedom from scrutiny and control. Distance from their corporation home is not always an objection to the incorporators. They can do the necessary communication with the authorities of the State or Territory where they incorporate thru the mails, and a two-cent stamp will cover a multitude of sins. The farther away they are from their corporation home often the better, for the more secure they are from attack thru the courts of the State or Territory which gives them birth. So it is that corporations doing business in Boston and New York are wont to incorporate under the laws of Delaware or West Virginia or Nevada or Arizona, and if anyone has a grievance the courts of these distant States and Territories may be open to them, but the prospect of a litigation three thousand miles from home is not alluring to the man who has rights to enforce. . . ."

The report reaches this conclusion as to State incorporation laws:

"The present system seems to offer:

"I. The maximum of protection for fraud;

"'2. The minimum of protection and convenience for honest dealing, and

"3. The best of opportunity for small States and Territories to fill their coffers with the proceeds of taxing outsiders, and the best chances for their petty public officials to get a good income without doing any work."

In 1909 the same Committee with a partially changed membership reported:

"In respect to the other branches of law, divergence among the laws of the various States has been a natural unconscious growth, whereas in the matter of incorporation laws, the divergences and variations have been to some extent, at least, knowingly and consciously created for the very purpose of inducing intending incorporators to avail themselves of what they are pleased to call the 'advantages' of the most liberal law. It has reduced itself in some quarters to a matter of competition for the incorporation business of the country."

Nothing will convince one more that the incorporation laws are ruinously competitive than an examination of the legal manuals whose purpose is to advise as to the best States for incorporation. If the laws were similar, one would incorporate in the State of physical domicile. But as they are dissimilar they are all frank in advising incorporation in the State most lenient with 
the corporations (but they do not add, most disadvantageous to the public). These incorporation manuals recommend this or that State because the fees are low, ${ }^{3}$ because the liability of stockholder and officer is at a minimum, because reports are infrequently required and especially because such a State is conservative and not likely to tamper with the already ascertained law.

"The lawyer 'will endeavor to obtain for his clients the maximum of benefit with the minimum of liability and expense.' In some States the corporation laws have not been changed. In others, however, a disposition has been manifested to hold out such strong inducements to intending incorporators as to result in a very close competition for the fees and taxes accruing from conferring the corporate privilege. In these States the provisions are so much more liberal than in the more conservative commonwealths that the attention of corporate counsel may well be confined to the following jurisdictions when selecting a domicile for his proposed company, viz.: Maine, Massachusetts, Connecticut, New York, New Jersey, Delaware, District of Columbia, Virginia, West Virginia, South Dakota, Nevada and Porto Rico."4

3 The following table shows the variation in the States in the cost of
incorporation:
$\begin{array}{rrrrrrrr}\text { Capital Stock. } & \text { N. J. } & \text { N. Y. } & \text { Del. } & \text { Maine. } & \text { S. D. } & \text { Wis. } \\ & \$ \quad 1,000.00 & \$ 35.00 & \$ 16.00 & \$ 35.00 & \$ 27.00 & \$ 13.00 & \$ 25.00 \\ 10,000.00 & 35.00 & 20.00 & 35.00 & 27.00 & 13.00 & 25.00 \\ 100,000.00 & 35.00 & 65.00 & 35.00 & 67.00 & 18.00 & 100.00 \\ 1,000,000.00 & 210.00 & 515.00 & 165.00 & 117.00 & 28.00 & 1,000.00 \\ 5,000,000.00 & 1,010.00 & 2,515.00 & 765.00 & 517.00 & 43.00 & 5,000.00 \\ 10,000,000.00 & 2,010.00 & 5,015.00 & 1,515.00 & 1,017.00 & 43.00 & 10,000.00\end{array}$

The following table shows the annual taxes in these same States:

$\begin{array}{rrrrrrc}\text { Capital Stock. } & \text { N. J. } & \text { N. Y. } & \text { Del. } & \text { Maine. } & \text { S. D. } & \text { Wis. } \\ \$ \quad 1,000.00 & \$ 1.00 & \$ 1.50 & \$ 0.50 & \$ 5.00 & \text { None } & \text { None } \\ 10,000.00 & 5.00 & 7.50 & 2.50 & 5.00 & \text { " } & \text { " } \\ 100,000.00 & 100.00 & 150.00 & 50.00 & 10.00 & \text { " } & \text { " } \\ 1,000,000.00 & 1,000.00 & 1,500.00 & 500.00 & 50.00 & \text { " } & \text { " } \\ 5,000,000.00 & 4,000.00 & 7,500.00 & 2,000.00 & 150.00 & " & \\ 10,000,000.00 & 4,250.00 & 15,000.00 & 2,150.00 & 275.00 & \end{array}$

The New York incorporation fee and the annual tax is higher than the New Jersey fee. This would seem to make New Jersey the better State. However, if business is to be done in New York, that State has a lever that almost compels incorporation under its laws. This is accomplished by having a license fee so high that it becomes cheaper to incorporate in New York than to pay the incorporation fee in New Jersey, plus the license tax in New York.

-Walter C. Clephane. The Origin and Management of Business Corporations, p. II. 
To the model set by these-the most lenient States-the other States are bound sooner or later to conform. The following extract continuing the above quotation illustrates this:

"The States are changing their corporation laws so rapidly that the foregoing list of eligibles is considerably longer than it was two years ago, and will doubtless be materially lengthened within the next five years."

\section{Another manual advises: 5}

"Speaking generally, however, the ease and cheapness with which incorporation may be secured in these localities draws to them most of the unsubstantial enterprises, illusive undertakings, and fraudulent schemes that adopt corporate guise for their dubious careers. These give character to the incorporations of these localities, and the very fact that a corporation is organized in a cheap State is in itself a circumstance requiring explanation and tending to discourage the experienced investor."

To this extent of course cheap incorporation defeats itself. Yet it is the inexperienced investor that must be protected, the other can well take care of himself.

This manual continues: ${ }^{\circ}$

"Up to I90I West Virginia had a virtual monopoly of the cheap incorporation business and derived therefrom a large and very profitable revenue."

The fees were then raised with the idea of increasing the revenue. But some things can be driven too far; the new fees were too high, and incorporators went to other States.

The evidence above is sufficient to show that the corporate laws of the States tend to drag down one another to the level of the lowest. Competition between the States produces a survival of the unfit, a truly anomalous situation.

The situation in insurance legislation is no different. In about a dozen States there are what are known as "retaliatory insurance acts." States having such acts are Minnesota, Wis-

Thomas Conyngton. A Manual of Corp. Org., p. 39.

- Page 40. 
consin, New York, Maine, Vermont and others. The Minnesota law, which is typical of the rest, is as follows: ${ }^{7}$

"Whenever by the laws of any other State or country any taxes, fines, penalties, licenses, or fees, in addition to or in excess of those imposed by the laws of this State upon foreign insurance companies and their agents doing business in this State, are imposed on insurance companies of this State and their agents doing business in such State or country, or whenever any conditions precedent to the right to do business in such State are imposed by the laws thereof, beyond those imposed upon such foreign companies by the laws of this State, the same taxes, fines, penalties, fees and conditions precedent shall be imposed upon every similar insurance company of such State, or country and their agents doing or applying to do business in this State, so long as such foreign laws remain in force."

What is the effect of such a retaliatory clause? It means that foreign companies can do business within a State to greater advantage than a local corporation, for the foreign corporation is protected by the retaliatory threat, which is sufficient to keep a State from taxing it heavily or regulating it properly. On the other hand, foreign corporations from States having no retaliatory clause may be subjected to taxes and conditions which disreputable companies coming from retaliatory States are not subjected to. This situation makes possible no end of bad legislation, no end of interstate confusion. Only one instance will be given to illustrate how the retaliatory clause operates. In 1906 the State of Wisconsin carried on an investigation of its life insurance companies. A witness for the Northwestern Mutual Life Insurance Company, of Milwaukee, testified that his company paid to the State of Wisconsin three hundred thousand dollars in taxes, and that its foreign competitors paid only a three hundred dollar license fee because of the retaliatory clause in the State of their origin. There were about twelve such States, and in all of these the Northwestern was doing business. Asked if the Northwestern favored a tax on foreign companies as high as his company was being taxed, the witness replied that this would only put an additional burden on the Northwestern,

${ }^{7}$ Minn. Laws of r9i r, R. L. '05, §1709. 
for every one of the States would retaliate by a similar tax, with the result that the Northwestern would have to pay about another three hundred thousand in taxes on its foreign business. This company preferred therefore to compete at a disadvantage in its home State rather than be at a greater disadvantage in its foreign business. Another witness stated ${ }^{8}$ that he favored the repeal of the retaliatory law of Wisconsin:

"Provided the State of Wisconsin at the same time would not impose taxes upon the other States doing business here, because if it did it would not help us any. They zould sandbag us under their retaliatory laws. But so far as the principle is concerned, the moral principle, I should be in favor of any State repealing the retaliatory laws."

Another described the retaliatory law as an "eye for an eye, a tooth for a tooth" doctrine. All agreed that the retaliatory laws were undesirable, and an almost unanimous agreement that the only hope for their abolition was in uniform action by the States.

The Report of the 1906 Wisconsin Investigating Committee was as follows: ${ }^{\circ}$

"Retaliatory laws appear to be enacted for the purpose,

"First: As a standing intimidation of the legislative bodies of other States in which life insurance companies are domiciled.

"Second: To inflict penalties upon foreign corporations, because of laws enacted by the State of their domicile.

"Unlike all other laws they find no justification in the necessities, conditions or demands of the people of the State. These laws while placing enormous burdens upon policy holders of this country, are of no benefit to the insurance companies. It is estimated that since their first enactment they have cost the policy holders in life insurance companies millions of dollars, without affording them one iota of benefit or protection.

"Under the operation of these laws, a deserving company from one foreign State may be burdened with restrictions and obligations as a condition of transacting a legitimate business beneficial to the citizens of this State, while another company from another State and of doubtful methods is admitted free from these exactions and burdens.

\footnotetext{
Report r906, Wis. Invest. 1300 .

- Report 1906, 228-9.
} 
"The State has a vital interest in the character, solvency and methods of all foreign insurance companies, transacting or proposing to transact business with citizens of this State: but neither the State nor the public can have any concern whatever as to the policy of any other State, upon the subject of the admission of foreign corporations. It is the privilege of each State to determine its own policy upon this subject, without intimidation or reference to the policy of any other State. Retaliatory laws are founded on a contrary conception."

The Committee recommended the repeal of the Wisconsin retaliatory law. It was of course not repealed, for it is a necessary protection so long as other States have a similar law.

The New York insurance "expose" and the "exposes" that have since swept over the country are sufficient demonstration of the deplorable condition of our State insurance laws. To be sure they have been much improved since. But no present improvement can be permanent, for one fact remains--the insurance laws of the States are competitive, and competition makes for laxity, for a survival of the unfit. ${ }^{10}$

${ }^{10}$ The following material is taken from the very thorough Report of Special Commissioners on the Taxation of Corporations made to the Connecticut Legislature in I9I3. On page 2I appears this: "One of the most serious defects in American taxation of corporations is the lack of uniformity of method among the several States. This is a source of constant expense and irritation to corporations that must be taxed in a number of different States. It leads to an unfair distribution of revenue as between the different States." The Connecticut Mutual Life Insurance Company in IgI2 paid a tax of $\$ 136,454$ to the State of Connecticut. In Pennsylvania the tax is about the same rate. By the Wisconsin method of taxing such companies it would have paid about $\$ 98,000$; by the Massachusetts method about $\$ 6000$, and by the New York method about $\$ 2000$. Yet companies in all these States compete with one another for the same kind of business. See report, page 159, at which the Commissioners conclude: "From the above facts it is evident that Connecticut imposes a considerably heavier burden upon her Mutual Life Insurance companies than is imposed on their own companies by certain other States in which are located most of the chief competitors of the Connecticut companies. This heavier burden must tend to increase the cost of insurance in the Connecticut companies. The Connecticut companies have to meet the competition of the other great insurance companies of the country, and if they are subject to a relatively heavier butden of taxation the result tends to unfairly burden them in this competition. . . . It would appear that some reduction in the burden of taxation was warranted, if for no other reason, in order to place the Connecticut companies on a more equal footing in their competition with the other insurance companies of other States." The report at page 67 shows that seventeen States use the gross earnings method of taxing Pullman cars. In these seventeen States, six have this tax in lieu of all other taxes, and the rate in these six States varies from one and one-half to seven per cent. 
However damaging competitive State laws may be in other fields, nowhere are they so disastrous to humanity as in the legislation surrounding industrial conditions. A corporation in one State competes with corporations in other States. Very naturally then it is interested in the conditions surrounding the industry of each of its competitors. A conscientious State may burden its corporations with one regulation after another, until the resulting increased cost of production will make it impossible for these to compete with their foreign competitors. No argument has halted reforms in industrial conditions more than the scare head: Beware! you will drive capital out of the State. No arguments catch the ear of the legislator more quickly. So well known in this sensitiveness of our legislators that it is appealed to in many cases where the reason does not exist. Here is the typical appeal of the capitalist: The reform you ask is desirable. We are heartily in favor of it. The present conditions are shocking and relief should come. We sympathize with your reform. But it must come by uniform action in all our competing States for otherwise you will drive us out of business. Reform in our State alone will ruin us. You will only destroy home industry for the benefit of the foreign. The industry may not be competitive to the degree argued, and possibly even if it were, the human appeal should count for mote than the economic. Nevertheless it defeats laws, modifies many others and delays more.

Let us examine a few instances in child labor legislation. The Rhode Island Child Labor Committee reported ${ }^{11}$ that the New England States were so closely knit by commercial and industrial ties, that all hope for reform legislation lay in uniform action. The report of the Louisiana Commissioners on Uniform State Laws ${ }^{12}$ deplored as an almost insurmountable barrier to reform the fact that each State was waiting for action from the others. Mr. Charles L. Chute ${ }^{13}$ attributed the chief opposition to child labor laws to the glass manufacturers who claimed that

\footnotetext{
${ }^{11}$ Ann. Am. Acad. 38: 183.

${ }^{13}$ Report, I912, II.

${ }^{13}$ Ann. Am. Ac. 38: 123 .
} 
the law would cripple their industry. So too in Illinois the manufacturers exclaimed: You will drive us out of the State. So the cotton manufacturers in the New England States and the Southern States stifle or delay child labor legislation-each for the fear of the other. The General Secretary of the National Child Labor Committee reported ${ }^{14}$ that New Jersey five times defeated the effort to abolish night work for children under fifteen years, because it was feared that with advanced laws the glass industry could not live in the State. The Committee on the Child Labor Law of the Commissioners on Uniform Legislation reported:15

"In the absence of such uniformity one manufacturer can gain an unfair advantage over another."

Mr. Lovejoy reports: ${ }^{16}$

"Because employers regard this inequality of law as a handicap they impress legislative committees, and this fact stands as a great obstacle to our work."

Mrs. Florence Kelley opposes a uniform child labor law because she believes some States will always lag in their legislation and that as time advances the distance between the most advanced and the most backward will grow larger. She says: ${ }^{17}$

"Certainly today, lagging is due not to apathy, not to lack of interest of citizens, but to the extraordinary efficient efforts of employers who believe it the direct advantage to the profits of their industry that the proposed step should not be taken."

Mr. Alton Parker ${ }^{18}$ predicted that all States would hesitate to pass workmen's compensation acts if these would place their contractors as a disadvantage. Mr. August Belmont, of the National Civic Federation, writes: ${ }^{19}$

"In view of the fact that a change from our present liability laws to the compensation principle will greatly increase the cost

${ }^{44}$ Ann. Am. Ac. 38: 186.

${ }^{25}$ I9I0, 193.

${ }^{28}$ Ibid., 67.

${ }^{17}$ Annals Am. Ac. 38: 25 .

${ }^{38}$ Mich. L. Rev. 8: 408.

"Report of Committee on Uniform Laws, 1910, 104. 
to employers, of liability insurance, from present indications, it is rendered doubly essential that there be legislation practically uniform, especially in industrial and competitive States."

Everywhere the employer rises with the vital objections: Do not make it impossible for us to compete with employers in other States, do not compel us to leave the State. So reform is checked in child labor laws, ${ }^{20}$ in laws regulating the labor of women, ${ }^{21}$ the hours of labor, machinery safeguards, workmen's compensation, ${ }^{22}$ industrial insurance, industrial diseases, minimum wages, factory legislation, in short in the whole field of

${ }^{20}$ Sixteen States have secured an. 8-hour day for children, although of course the age limit in these States varies, so that even in these States the conditions are not similar. It is worth noting that no New England State and no Southern State except Mississippi, is one of the sixteen States. May one suggest that the competition of these two sections in cotton manufacture may have some relation to the laws. In Ohio the 8-hour law applies to all girls under 18 ; in New York to all boys and girls under 16 that are engaged in manufacturing; Utah and some other States have an 8-hour day for all engaged in mines; and below these the requisites vary to a base of no requirements. In I913 thirty-one States passed legislation affecting children.

${ }^{21}$ Legal maximum of women in manufacture:

Less than ro hours a day

Io hours in one day

Over Io hours in one day

No limitation

48 to 54 hours a week

55 to 60 hours a week

Over 60 hours a week

No limitation

$\begin{aligned} 5 & \text { States } \\ 10 & \text { " } \\ 4 & \text { " } \\ 28 & \text { " } \\ 16 & \text { " } \\ 3 & \text { " } \\ 22 & \end{aligned}$

Legal maximum in mercantile establishments:

Less than ro hours a day

Io hours in one day

Over Io hours

No limitation

48 to 54 hours a week

55 to 60 hours a week

Over 60 hours a week

No limitation

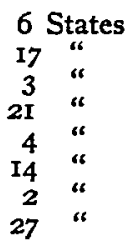

* Twenty-two States have passed workmen's compensation acts. The insurance to cover compensation varies from private insurance, the rule in most States, to compulsory insurance by the State, as in Washington; in Nevada the State insurance is optional, and in California the State has an insurance fund in order to guarantee fair competition between the companies. The schedule of employments varies greatly in all these acts; some covering "hazardous" employments as in Oregon; some "extra hazardous" employments as in Washington (following this with a definite schedule of the employments covered); some include all but railroads as New York; some all except farm labor as Towa; some all employments of over five men as Texas; some except casual labor. Some of the States deprive workmen of compensation if the injury was received while intoxicated, some if willful 
industrial life. This argument more than any other prevents, modifies or postpones industrial reforms. Only when an evil reaches sensational dimensions does the manufacturer give way. And there is small hope for change since the States are competitive units. The conscientious State is at a disadvantagereform is at a disadvantage. The lax State sets the standard, it has a depressing influence which only the most unusually selfsacrificing State will ignore. The tendency is plain-in industrial legislation the State laws are a survival of the unfit. Why? Because the States are industrially competitive.

The evils of the diversity of our State divorce acts need only to be mentioned. The time is hardly yet passed when States were actively advertising for the divorce business. The divorce laws were competitive to the most degrading degree. Public opinion fortunately has upon this problem been so strong that many of these business States have been shamed into "tightening" their laws. Yet even today we have the States varying in their grounds for divorce from those in which there are no grounds for divorce to those in which there are over a dozen. The only effect of no or of few grounds for divorce is that the parties go to the States where there are many grounds and where they can easily secure a divorce. So even today the great evil in the divorce situation is that the laws are really competitive, though perhaps no longer intentionally so.

In taxation laws there is no more troublesome question than that of the situs of property in different States. When it is possible to tax the same property three times in different forms, there is just cause for complaint. With situs variously interpreted, tax laws are competitive. The call of the Taxation Committee of the National Civic Federation in IgoI illustrates another phase of the competitive side of tax legislation:

"For some years the dissatisfaction with our methods of taxation, both State and local, has been growing apace. We

or intentional, and others allow recovery even in these cases. The amount recovered for death varies wherever lump sums are paid from $\$ 1000$ to $\$ 5000$; and in States where 300 half weekly payments are made from a minimum of $\$ 4$ to $\$ 6$ to a maximum of $\$ 10$. The other schemes vary so much that comparison is practically impossible. 
have been so long accustomed to a system which was suited to the early conditions of American life, that we are only slowly awakening to its shortcomings in the light of modern business activity. Industry has overstepped the boundaries of any one State, and commercial interests are no longer confined to merely local lines. Corporate activity has largely changed the character of personal property and individual investments.

"The problem of just taxation is no longer a local problem. It cannot be solved without considering the mutual relations of contiguous States and localities. An unequal tax on the farmer in one State may make it difficult for him to sell his products in the world's markets; and unjust tax upon the manufacturer or business man may drive him out of business; an unfair tax on the corporation or business may cause it to move to another State. Any action by any one commonwealth evidently reacts upon its neighbor."

The Conference attempted to ascertain a single situs for each subject of taxation. The next problem was to induce all the States to accept this single situs idea. And of course no State has accepted it. Why? Because all the States are competitive. Any State that would be progressive in such action would only be tying its own hands, and offering a new weapon to its competitors. So the comedy and confusion of conflicting claims as to the proper situs for taxation goes on.

The State bird and game laws are in a similar condition. Each year the ravages of this or that insect cause the loss of millions of dollars to our crops. In fact an expert like Dr. C. L. Marlatt estimates the annual insect damage in the United States at eight hundred million dollars. Now each of these destructive insects has some natural enemy in the form of this or that bird. The minimizing of crop destruction therefore lies in encouraging the propagation of insectivorous types of birds. But that has been impossible because State bird laws are competitive. For example one State protects robins and blackbirds, while another prefers to give its inhabitants this source of food. These birds are migratory. What is the result? They are protected in one State and slaughtered in another. Any State that conscientiously protects birds does so only for the benefit of the people of another State. It will therefore be tempted to wipe out the prohibition, and here again as in other instances 
cited the law of the State with the most elastic conscience, becomes the law of all. One lenient State drags down all the others, for the laws protecting birds are competitive. And the hordes of insects go on multiplying and enjoying themselves at the nation's expense.

Again take game birds like ducks and geese. These have been decreasing in numbers to the extent that it became necessary to allow only fall shooting. A few egotistic States, however, allowed spring shooting, and with what result? Protected in one State the ducks were slaughtered in another. And the conscientious States were virtually compelled to return to spring shooting. All were forced to the standard of the lowest, another triumph, an added instance of the survival of the unfit. The federal law regulating the killing of migratory birds is a recognition of this fact.

The above instances have been sufficient to show that State laws in certain fields are subject to a competition which virtually makes it impossible for the States to enact sane social legislation. They are compelled to consider in the drafting of a law, facts which should have no bearing upon their action. Facts beyond the confines of the State are made to determine the form of State legislation. The real issue in much legislation may only receive secondary consideration. In every one of the instances cited, one condition was present-the laws were competitive, and it was this competition that brought all the evils with it. No State is to blame for the bad laws-it is a fault of the system. In certain fields of business we have found that competition has always brought with it serious evils, and we have substituted the larger unit of monopoly.

Why not follow the same policy in these fields of State law? If the State unit of legislation is too small, if with the State unit the evils of interstate competition are connected, why not ignore the unit? Why not make our laws in these fields national? Accordingly uniform laws have been proposed on each of the subjects above considered. A federal law would be the easiest solution for these difficult situations, but in every case a federal law would be unconstitutional. In view of the 
difficulty of amending the Constitution, the Commissioners on Uniform State Laws have for over twenty years tried to get the States voluntarily to adopt laws on subjects in which uniformity was desirable. But in this movement, they have had only mediocre success.

Some States have fought this inevitable competitive tendency, but no State can permanently fight such a tendency; the cost of the sacrifice is too great. Sooner or later the conscientious States, in the face of the unrelenting selfishness of other States, will become impatient of their own heroic self-sacrifice. They will follow the path of least resistance, that to which economic facts and the form of government force them. Every State then in varying degrees at different times, depending on the state of the public conscience, is subject to the degrading influence of this "against-their-will" competitive situation. And against their will, yet with it, we have competitive exploitation of the public, and an inevitable friction where no one desires it. Last of all we have an apparent anomaly-The State Laws: A Survival of the Unfit.

The only remedy that presents itself is to amend the Constitution of the United States so that Congress can pass laws on every subject in which the competitive principle is involved.

University of Wisconsin.

Raymond T. Zillmer. 